Article

\title{
Critical Omissions and New Directions for Sustainable Tourism: A Situated Macro-Micro Approach
}

Tazim Jamal $^{1, *}$, Blanca A. Camargo ${ }^{2, \dagger}$ and Erica Wilson ${ }^{3, \dagger}$

1 Department of Recreation, Park and Tourism, Texas A\&M University, 600 John Kimbrough Blvd 409M AGLS, 2261 TAMU, College Station, TX 7706, USA

2 International Tourism Program, University of Monterrey, San Pedro Garza Garcia, NL 66238, Mexico; E-Mail: bcamargo@udem.edu.mx

3 School of Tourism and Hospitality Management, Southern Cross University, PO Box 157 Lismore, NSW 2480, Australia; E-Mail: Erica.wilson@scu.edu.au

$\dagger$ These authors contributed equally to this work.

* Author to whom correspondence should be addressed; E-Mail: tjamal@tamu.edu; Tel.: +1-979-845-6454; Fax: +1-979-845-0446.

Received: 29 July 2013; in revised form: 24 August 2013 / Accepted: 30 September 2013 /

Published: 29 October 2013

\begin{abstract}
This paper traces the history and evolution of sustainable tourism and identifies some critical issues and omissions in this and related approaches such as responsible tourism, ecotourism and pro-poor tourism. The academic, institutional and practical intersections of sustainable tourism and responsible tourism are examined. It reveals that important theoretical and practical considerations around well-being, inclusion, and sustainability have been omitted. A critical look at ecotourism reveals additional concerns, such as a cornucopia of guidelines and principles, without clear ethical justifications to support them. At the same time, academics in this domain have been slow to consider the modernist and neoliberal influences shaping ecotourism and sustainable tourism development, such as through the discourse of ecological modernization. We identify some key omissions, such as the missing 'body' in sustainable tourism discourse, lack of critical analysis of postcolonial and dependency issues, and propose re-situating 'sustainable tourism' within a micro-macro, local-global systems approach informed by a clear framework of justice and ethics.
\end{abstract}

Keywords: sustainable tourism; responsible tourism; critical research; justice and ethics 


\section{Introduction}

This timely Special Issue raises challenging questions as well as opportunities for how we might think differently about sustainable tourism. Much of tourism research to date has focused on understanding the relationship between human activity and impact — a largely scientific question —and has been strongly influenced by the discourse of sustainable development launched by the Brundtland Commission's Report [1]. While steady progress has been made on developing strategies and tools to address conservation and sustainability, critical research that tackles aspects such as the interests, values and agendas that shape various approaches to sustainable tourism development has been slow to emerge (cf. [2,3] for early critique). Admittedly, disciplinary fragmentation has to some extent hidden and exacerbated these challenges. In this paper, we identify and discuss critical gaps, such as related to human-environmental relationships, gendered and feminist perspectives, diverse populations, and the pro-poor agenda. It is argued here that sustainability requires not only that people care about the future, but also care about the 'Other', the well-being of living things and their relationships with the material world that sustains them physically, socially, emotionally and, for many, spiritually. What is required is an integrated tourism paradigm that addresses resources conservation in a way that does justice to the situated 'body', the "Other" of tourism destinations. The purpose of the paper is therefore three-fold:

(1) To trace the history and discourse of sustainable tourism plus alternative approaches (like responsible tourism), as well as the parallel evolution of forms, like ecotourism. We examine also the discourses of sustainable development and ecological modernization that are seen to play an influential role in shaping these concepts;

(2) To identify and discuss some key issues and omissions that are revealed in the excavation conducted above, including the challenge of address intangible cultural relationships such as human-environmental relationships in ecotourism;

(3) To forward some conceptual approaches and practical directions to better situate sustainable tourism within a framework based justice and an ethic of care.

To address the three aims above, we engage a critical perspective, uncovering and unpacking the often unspoken political structures and power imbalances inherent in the sustainable/responsible/ ecotourism discourses. While a notable 'critical turn' is taking place in the field of tourism studies $[4,5]$, too little of this has focused specifically on sustainable tourism. Much of the academic research around sustainability and tourism has centered on an abundance of definitions, certification schemes, and the science of tourism impacts. While important issues, indeed, what is simultaneously missing in this agenda is a focus on the voices and experiences of the 'Other', such as of those who are most affected by tourism change but least able to speak for themselves, and of those who research tourism from their side.

To begin with, and in the context of this Special Issue, it is first important to revisit the origins, development and debates around the key concepts of responsible tourism and sustainable tourism, two enduring and popular approaches to sustainability that have influenced tourism studies. 


\section{Responsible Tourism and Sustainable Tourism: Evolution and Critique}

Several forms of tourism started to emerge in the 1980s in reaction to growing awareness of the negative impacts of mass tourism. They were described variously as 'alternative', 'appropriate', 'sensitive', 'authentic', 'just' tourism [6], as well as 'soft' and 'humane' tourism. Despite the variability, they seemed to have in common a desire to reduce the negative impacts and exploitation brought by mass tourism while ensuring that the local community received a just share of benefits and were accorded respect. Almost 30 years ago, Krippendorf ([7], p. 19) made a very explicit call to all suppliers of tourist services "to acknowledge their responsibility towards travelers, the host population and the tourist environment, to state clearly what contributions they are prepared to make to a more human tourism and what regulations they are willing to observe" (p. 19). Haywood [8] encouraged local governments to recognize that they would have to become more responsible to the local citizens whose lives and communities were affected by tourism. Responsibility, according to Haywood, was to be at the core of tourism planning, encouraging a participatory approach and introducing techniques to formulate community-based goals and strategies for tourism.

A formal definition of responsible tourism was crafted and adopted in 1990 at a seminar on alterative tourism in Algeria, which referred to as "all forms of tourism which respect the host natural, built, and cultural environments and the interests of all parties concerned" [9]. Over the next decade, descriptions varied widely from a way of doing tourism policy and planning [10], or doing development, marketing and management in a responsible way [11] that provided better holiday experiences and business opportunities [12], and maximized benefits to the local community while ensuring that adverse impacts were limited [13]. Overall, responsible tourism was seen as a concept that embraced a supposedly more caring, aware form of tourism, as Wheeller [14] noted.

An attempt to capture the key principles of responsible tourism was made in the Cape Town Declaration that emerged from the conference organized by the Responsible Tourism Partnership and Western Cape Tourism, which was a side event preceding the United Nations World Summit on Sustainable Development in Johannesburg in 2002. The Earth Summit 2002 was convened to address pressing issues of poverty and global environment degradation. This was an important setting, for responsible tourism proponents had also facilitated the emergence of pro-poor tourism in the 1990s, with South African stakeholders showing leadership and vision in this initiative. The Cape Town Declaration on Responsible Tourism in Destinations strove to incorporate local South African knowledge and experience into responsible tourism guidelines that were field tested in and around Cape Town (see [15]). Of key importance was that it:

- Minimizes negative economic, environmental, and social impacts;

- Generates greater economic benefits for local people and enhances the well-being of host communities, improves working conditions and access to the industry;

- Involves local people in decisions that affect their lives and life chances;

- Makes positive contributions to the conservation of natural and cultural heritage, to the maintenance of the world's diversity;

- Provides more enjoyable experiences for tourists through more meaningful connections with local people, and a greater understanding of local cultural, social and environmental issues;

- Provides access for physically challenged people, and 
- Is culturally sensitive, engenders respect between tourists and hosts, and builds local pride and confidence

Alongside rising criticisms of the concept of responsible tourism (see [16-18]), the first decade of the 21 st century saw attention shifting to implementation strategies. During this period, tourism organizations developed specific and practical guidelines for tourists and for the industry as a whole. Guidelines were developed for tourists, for example, such as: 25 Practical Ways to Make a Difference [19], The Responsible Tourist and Traveller Guidelines [20], and The Responsible Travel Handbook [21]. Tour operators and other tourism businesses joined in as well. The Association of Independent Tour Operators (AITO), for instance, proposed a set of guidelines intended to help companies, customers and local suppliers recognize their common responsibilities to protect the environment, respect local cultures, benefit local communities, conserve natural resources, and minimize pollution [22].

Following the official 1996 White Paper: The Development and Promotion of Tourism in South Africa [23], South Africa continued its leadership and launched the South African National Responsible Tourism Guidelines [24]. This document provides explicit guidelines, objectives, and indicators related to economic, social, and environmental responsibility. In 2008, the Second Conference on Responsible Tourism in Destinations developed the Kerala Declaration on Responsible Tourism [25]. Based on the guiding principles for economic, social and environmental responsibility from the Cape Town declaration, the Kerala declaration focused on specific processes and approaches to implementation. Meanwhile, academic interest and research continued. For instance, the 2008 Special Issue on Responsible Tourism in the Journal of Sustainable Tourism addressed a range of topics from expectations of responsible tourists in New Zealand [26] to measuring responsibility through the appraisal of sustainable tourism indicators [27]. Table 1 summarizes some of the key markers in the evolution of responsible tourism.

Table 1. Chronological evolution of Responsible Tourism.

\begin{tabular}{|c|c|}
\hline Timeframe & \\
\hline Late 1980s & $\begin{array}{l}\text { - First calls for responsibility are made: To suppliers of tourism services [7], to governments for } \\
\text { responsible tourism planning [8] }\end{array}$ \\
\hline Early 1990s & $\begin{array}{l}\text { - First definition emerges: "All forms of tourism which respect the host natural, built, and cultural } \\
\text { environments and the interests of all parties concerned" [9] } \\
\text { - Criticisms arise: Responsible tourism as dangerously superficial, ephemeral and inadequate [14] }\end{array}$ \\
\hline 1996 & $\begin{array}{ll}\text { - } & \text { RT is embraced by a national government (South Africa) } \\
\text { - } & \text { First concrete principles of responsible tourism emerge } \\
\end{array}$ \\
\hline 2002 & $\begin{array}{ll}\text { - } & \text { Responsible Tourism Manual (South Africa) } \\
\text { - } & \text { First Conference on Responsible Tourism in Destination, Cape Town, South Africa } \\
\text { - } & \text { Cape Town Declaration: Expanded definition of responsible tourism and guiding principles } \\
\text { - } & \text { International Center for Responsible Tourism is born } \\
\end{array}$ \\
\hline Mid 2000s & $\begin{array}{l}\text { - Development of Guidelines and Codes of Conduct } \\
\text { - } 25 \text { Practical Ways to Make a Difference [19] } \\
\text { - The Responsible Tourist and Traveller Guidelines [20] } \\
\text { - The Responsible Travel Handbook [21] } \\
\text { - } \quad \text { Responsible tourism becomes a marketing tool and profitability enhancer }[24,28]\end{array}$ \\
\hline
\end{tabular}


Table 1. Cont.

\begin{tabular}{ccl}
\hline Timeframe & \\
\hline \multirow{2}{*}{2008} & $\bullet$ & Second Conference on Responsible Tourism in Destination, Kerala India \\
& - & Kerala Declaration on Responsible Tourism: Processes and implementation \\
\hline & - & Renewed academic interest in responsible tourism \\
\multirow{2}{*}{ 2008- present } & - Journal of Sustainable Tourism special edition on Responsible Tourism \\
& - Books on Responsible Tourism (e.g., [29]) \\
& - First journal dedicated to Responsible Tourism research: Progress in Responsible Tourism \\
\hline $\mathbf{2 0 1 0}$ & - & First World Responsible Tourism Day \\
\hline $\mathbf{2 0 1 1}$ & - & World Responsible Tourism Award is born \\
\hline
\end{tabular}

Responsible tourism is commonly misperceived to be an aspect of sustainable tourism [see 26]. However, its evolution and local focus is distinct and in sharp contrast to the development of the concept of "sustainable tourism", which has been strongly shaped by academic and institutional interests. Influenced by the notion of sustainable development forwarded in the Brundtland Commission's Report Our Common Future [1]: Sustainable development was defined in this report as "development that meets the needs of the present without compromising the ability of future generations to meet their own needs" ([1], p. 8). It brought sustainability into the political arena with a worldwide influence on governments and non-government organizations (see [30], for a discussion on sustainable tourism development and the WCED [1] initiative. Also see [31,32].); the United Nations World Tourism Organization (UNWTO) [33] adopted the following definition of sustainable tourism development.

Sustainable tourism development meets the needs of present tourists and host regions while protecting and enhancing opportunity for the future. It is envisaged as leading to management of all resources in such a way that economic, social, and aesthetic needs can be fulfilled while maintaining cultural integrity, essential ecological processes, biological diversity, and life support systems (p. 30).

The concept proliferated over the next decade and has seen continued attention from academic researchers as well as institutional advocates (see [34-38]). The UNWTO approach continued to emphasize balance among three areas, following the Brundtland Commission's approach for sustainable development [1,33], while academics and researchers continued to experiment with grounding it in more concrete terms of host communities, tourist experiences and the tourism industry [33,39].

The UNWTO also continued to draw from the UN World Summits. Subsequent to the Earth Summit in Rio in 1992, the World Travel and Tourism Council (WTTC), jointly with the UNWTO and the Earth Council, developed Agenda 21 for the Travel and Tourism Industry. It translated Agenda 21 into a program of action for travel and tourism. In addition to specifying that the travel and tourism industry contribute to ecosystem conservation, restoration, and protection, this document also called for local decision making and participation of concerned citizens in tourism development issues, employment generation for women and indigenous people, and recognition and support of the identity, culture, and interests of the indigenous people. How these latter goals were to be attained in terms of not only implementation but also regulation is not clear. 


\subsection{Critical Micro-Macro Intersections and Clash of Perspectives and Values}

While the two approaches described above emerged from similar concerns in the 1980s-early 1990s, they differed in a number of ways, including the drivers to their inception, their areas of concentration and the degree of institutionalization involved. Emerging from the search for alternatives to mass tourism, responsible tourism focused on micro-level, action-oriented, community-level approach, oriented towards a concern for nature, culture, humans (tourists and residents included) and the living/non-livings systems in which they lived. Respect and care are important values in responsible tourism, and attention to disadvantage, unfairness and poverty is evident. Its stakeholders include NGOs and religious interests (e.g., the Ecumenical Coalition that raised concern about sex tourism in Asia), public and private sector interests (e.g., the South African government and its efforts for local level engagement with responsible tourism and pro-poor tourism), and academic centers such as the International Center for Responsible Tourism.

Sustainable tourism, by contrast, has evolved and grown through a mix of academic, public-private sector organizations and global, institutionalized structures of governance whose stakeholders include the WTTC and the UNWTO, both of which have shaped sustainable tourism development since the first UN Earth Summit in 1987. While disseminating numerous planning and development guides, the UNWTO is oriented towards macro-level issues and objectives, e.g., global institutional governance for sustainable travel and tourism development, structural inequalities including social and gender inequities, poverty alleviation, etc.) [40,41]. The Global Sustainable Tourism Council (GSTC) established in 2010 was result of the merger between GSTC and the Sustainable Tourism Stewardship Council (STSC). It serves as an international body to disseminate knowledge and encourage adoption of sustainable tourism practices. Members of the GSTC include travel companies, hotels, national tourism boards, tour operators and UN agencies including UNWTO, UNEP and the UN Foundation.

A range of criticisms has targeted the concept of sustainable tourism, however, some which pointed to the instrumental and utilitarian discourse of sustainable tourism development influenced by WCED [1], where development entailed long-term "balancing" of use and conservation/preservation towards the ends of inter-generational and intra-generational equity. An emphasis on community-based tourism as a key principle of sustainable tourism then arose to facilitate local control and community participation (see, for example, [39]). Critics like Butler [42] pointed out ambiguities in the term sustainable tourism; for example, does it mean an industry-oriented perspective of sustaining tourism in the long-term in the destination? Some scholars attempted to reconcile sustainable tourism better with the broader WCED [1] paradigm of sustainable development (see [30,43]). Font and Harris [44] pointed out the omission of social indicators in sustainability-oriented certification schemes. Several scholars challenged the interests of sustainable tourism in the context of the developing world (e.g., [2]). Yet very few questioned its continued adherence to modernization's ideological pillars (cf. [3]). This lack of critique has slowed our understanding of the rationalization of nature and culture occurring under 'sustainable tourism' and its nature-based companion, ecotourism. A renewed look at this concern is especially merited in light of increasingly neoliberal landscapes of globalization and global free trade [45].

Deconstructing the rhetoric of sustainable development, communications scholars like Peterson [46] argued that the approach employs modernity's ideas of progress: technological and industry-driven 
growth, confidence in science as the dominant mode of knowledge, reliance on science and technology for (ecological) modernization, and resource conservation and management. Sustainable development from this perspective is highly anthropocentric [47]; it "is about sustaining development as an economically rationalized environment rather than the development of a sustaining ecology" ([48], p. 85). Techniques such as carrying capacity, cost-benefit analysis and indicators for measuring change, apply rational-instrumental means to control and manage people as well as nature, facilitating neoliberal intrusions (see [49]).

The UNWTO's adoption of sustainable tourism (development) drew upon the Brundtland Commission's paradigm of sustainable development, and was seen to incorporate its anthropocentric values ([47], see also [50,51]). Critical scholars also argued that rhetoric of sustainable tourism development underpins a faith in expert systems, both scientific and technocratic, and a belief in economic 'development' that is viewed as growth-oriented progress (within 'limits' of course). Ecological modernization and managerialism are perceived here as two key ideologies for the use and control of nature and people as a 'resource'. They are also common tools of neoliberalism under globalization; state power and authority to regulate sustainability infractions and actions is seen to be eroding aided by a powerful rhetoric of public-private sector 'cooperation', the dominant narrative of science, and the perceived societal benefits of various technological advances [52].

At risk in the instrumental focus on reducing uncertainty in modern life and enabling 'progress' (modernism's view of this in terms of economic growth) are the voices and needs of those who are impacted on by these measuring devices, in particular, the inhabitants of the areas concerned. Note that "economic growth" rather is still part of the discourse in Rio+20 [41], despite numerous alternatives like the UN Human Development Index (UNHDI) and other indicators that point towards the merit of replacing "growth" with terms like "well-being" or even "development" that could be guided by indicators like UNHDI, or other quality of life indicators, and capacity building parameters (see, for example, [53-55]). Responsible tourism is not immune to this concern either. Despite noble principles like benefit sharing, and values denoting respect and care for residents and the ecological-cultural spaces they inhabit, its local level micro-focus tends to decontextualize it from the broader geopolitical landscape and macro-level activities towards global institutional governance, leaving it vulnerable to better understanding and resisting of neoliberal intrusions. A close look at the conservation-driven discourse of ecotourism, reveals a danger of eschewing emotion, care and respect (values favored in responsible tourism approaches) as people and places are subject to the dual objective and material 'gaze' of business and science.

\subsection{Ecotourism and the Discourse of Ecological Modernization}

Most "green" theories and practices, however, increasingly centre on "grey" outcomes-who will "denature" Nature for whom, in what ways, for how long, to serve what ends? -although they often raise this very ineffectively with few original insights into what is really unfolding here. ([48], p. 197).

Unlike the roots of sustainable tourism and responsible (or alternative tourism), the evolution of ecotourism can be traced back to growing concerns in the late 1970s and early 1980s about tropical forest conservation, habitat loss and environmental degradation. In 1983, Héctor Ceballos-Lascuráin was in Mexico City, working for PRONATURA, a Mexican NGO lobbying for the conservation of a 
wetland area. His vision of tourism's role in ecological conservation and rural economic development was captured in the term he referred to as ecotourism [56-60]. It adopted a view that had been embraced by the conservation movement overall - the alternative income hypothesis: If alternative, more sustainable, economic activities were made available, local residents engaged in unsustainable environmental activities could shift to these in order to generate income [61]. In addition to reducing resource exploitation, they could become stewards of the ecosystem. Conservation was a primary motive in the early days of ecotourism's evolution, and the generation of economic benefits to local inhabitants was perceived to be a mutually beneficial means to this end.

Over the next decade, ecotourism's "alternative" potential stimulated academic and practical attention to the creation of new protected areas [62,63] and Ceballos-Lascuráin's vision of this form of "environmentally responsible travel" was adopted by the International Union for Conservation of Nature (IUCN) in 1996.

Ecotourism is environmentally responsible travel and visitation to relatively undisturbed natural areas, in order to enjoy and appreciate nature (and any accompanying cultural features - both past and present) that promotes conservation, has low negative visitor impact, and provides for beneficially active socio-economic involvement of local populations. (Ceballos-Lascuráin, adopted by IUCN [64])

The now widely cited International Ecotourism Society's definition [65] pares the above down to two priorities: conservation and attending to the local people who inhabit the area. The visitor, tasked to "enjoy and appreciate nature (and accompanying cultural features) is whittled down to "responsible travel" here:

Ecotourism is defined as "responsible travel to natural areas that conserves the environment and improves the well-being of local people." [65]

Further criticisms of the ecotourism concept challenged the interests and values driving it, and attempts to strengthen various dimensions have emerged [66-68]. However, the ecotourist remains an enigma, even though learning and ethical behavior have been forwarded by some academics as key principles [69]. Are the generally wealthy visitors (consider the costs of seeing gorillas in the mist of Rwanda-Burundi) ecotourists or "egotourists"? ([2]). Critics also raised concerns about ecoimperialism [70] and about its embracing of ecological modernization. The discourse of ecological modernization is a paradoxical ideology based on the claim that environmental conservation is good for business profitability and long-term economic development [71,72]. Critics argue that this laudable view is deeply flawed as, ironically, it is driven by Eurocentric views and modernist values of "progress" that are achieved through the contributions of science and technology, and measured in terms of economic growth. They are dominant narratives justified by the powerful claims of objective science - the scientific management principles, and the economic-ecological modernization theses embraced by the conservation community and related ecotourism interests make it difficult for alternative (non-modernist) narratives or non-anthropocentric perspectives like biocentrism to gain voice $[47,50,73]$.

Ecotourism certification programs can exacerbate the 'disenchantment' of Nature [74,75]. They proffer a set of widely generalized environmental, economic and social indicators aimed at monitoring, 
controlling and ensuring conservation and socioeconomic benefits. However, they are generally embedded in technical and scientific discourses, paying little attention to cultural sustainability and especially ignore the complexity of ethical and human-environmental relationships. Green governance through certification programs is seen critically to take the form of a global environmentality [76,77] dominated by scientific, environmentalist, governmental and business discourses. Market-oriented managerialism and ecological modernization offer efficient, scientific and technologically driven solutions. Other values, however, such as those associated with traditional knowledge, spiritual relationships and cultural heritage, risk being colonized by these globally dominant scientific-technical narratives (see $[71,78,79]$ ).

Drawing upon Wearing et al. [80], Jamal et al. [79] argue furthermore that the evolution of ecotourism as a market-based approach to conservation has institutionalized a commodified paradigm where the environment and its inhabitants (human and non-human) are treated primarily as means to an end; that is, instrumentally. Human-environmental relations are changed in important ways through the commodification process but the implications of consequential intangible social-cultural changes tend to be poorly understood. Further, they are not factored into the 'cost-benefit' analyses of ecotourism development or certification as these operate predominantly on quantitative, measurable indicators.

Paige West [81], for instance, argues for placing the politics of translation and theories of value and spatial production at the center of environmental anthropology. She describes a project in which the Gimi-speaking peoples of Maimafu village, Papua New Guinea, participated in an integrated conservation and development project trying to foster a local system of valuing "nature" by using eco-enterprises to link biological diversity to economic markets. However, the project failed to recognize how Gimi experience their forest world, and how they express knowledge. Subjectivity and "being-in-the-world" is a constant, dynamic production that lies at the heart of Gimi politics of environment and occurs through mutual recognition between individuals, between people and their ancestors, and between people and animals. It is "the way that Gimi see "self" and "other"- - be that other another person, an ancestor's spirit, or a tree kangaroo. Gimi are in existence in relation to their forests and their forests are in existence in relation to Gimi; there is no Gimi without forest and no forest without Gimi” ([81], pp. 638-639).

What is needed according to many concerned scholars, therefore, is a decommodified paradigm that acknowledges the local-global performative space of ecotourism in which external discourses intersect with local ones. It is a paradigm where people are not treated nearly instrumentally as means to an end, but are also treated as ends in themselves - with respect and acknowledgment of the cultural relationships with the natural world. This paradigm would also draw upon locally-situated, embodied perspectives, understanding what it means for those who dwell in that place to live well with ecotourism [82]. Sustainable tourism principles, as argued in the next section, must address justice and care for the "Other" and their intangible cultural relationships with the world in which they are embodied and embedded in everyday life.

\section{Filling in Some Critical Gaps and Omissions}

The previous sections of excavation on the evolution, interests and values influencing sustainable tourism, responsible tourism and ecotourism raise some critical and worrisome questions: 
How clear are the ethical guidelines and goals of ST and ecotourism? What interests shaped these? What's missing? Do they provide clear directions and principles of justice and ethics, to address issues related to, among others, diversity, race and ethnicity, gender, pro-poor/poverty alleviation, equity and inclusivity?

Tourism research, located within the field we loosely call 'tourism studies' has historically been influenced heavily by traditional, positivist, and predominantly quantitative approaches [83-85]. It could be argued that the criteria and indicators in tourism-related certification schemes have similarly focused on such positivist, quantifiable indicators, eschewing harder to measure qualitative, intangible dimensions like cultural relationships to the land. Fortunately, change is afoot, in the form of increasing recognition of the importance of qualitative and critical research approaches tackling, for instance, ethical gaps and issues related to disadvantage and injustice among ethnic minorities and other diverse groups (see [86]).

Those advocating for a critical, ethical or feminist tourism studies argue that spaces and places are social as well as physical constructions, shaped by complex gendered, cultural, racial and power relations [87]. In this vein, a number of scholars have envisioned or explored the ethical turn in tourism and the various prescriptions being forwarded for social justice or a tourism that is not only more efficient, but also more responsible, more conscientious, more just, and more spiritually rewarding ([88,89]). While Duffy [47], Holden [50], Hunter [51] and Macbeth [90] grapple with issues related to environmental ethics, political economy and political ecology, a few critical researchers have begun directly to call for justice oriented forms and approaches to tourism [91,92]. Critical and concerned voices are also emanating directly from postcolonial destinations that are addressing neocolonialism, commodification, and exclusion in the context of tourism [93-95]. However, our excavation above reveals two further pressing issues that we strive to address below:

\subsection{The Missing 'Body' in Critical Sustainable Tourism Research}

The fledgling field of 'tourism studies' in the 1980s and early-mid 1990s was missing 'the body' in tourism, as Veijola and Jokinen [96] observed in their quirky, trenchant critique which found them on an imaginary holiday with a number of leading tourism scholars of the time. By 'the body', Veijola and Jokinen were referring to a lack of the subjective, emotional and personal voice in tourism research, and a reliance on essentialist categories of tourism/tourist, particularly on the host as the objectified 'Other'. According to Veijola and Jokinen (as cleverly pointed out in the imaginary dialogue technique through which they wrote their paper), there was also no 'body' in tourism methodology, with researchers remaining as nameless and genderless. Since that time, progress on acknowledging the body in tourism continues to be slow, apart from some of the moves afoot in critical, feminist, and ethical tourism as discussed above. As in the early knowledge base, sustainable tourism research was gathered through Eurocentric and Western gazing on self and the "Other", and cast in the languages of the west (English predominated in tourism journals). Greater attention is needed in sustainable tourism research in terms of its consideration of indigenous people, women, minority ethnic groups, and poor populations in many regions who stand to be impacted greatly by tourism and neoliberal agendas. It is also important to note that the 'body' in tourism may be diversely, 
infinitely gendered, physically challenged, ethnically oppressed, or situated in the in-between spaces of touristic places $[95,97]$.

Key questions that remain unresolved if not ignored in the (disembodied) sustainable tourism discourse are ones such as: How well have we progressed with respect to research on women and gender in sustainable tourism? What has happened to the environment in ecologically sustainable tourism, and what of environmental justice in tourism? Furthermore, how much progress has been made in studying and enabling the participatory voices and perspectives of indigenous and Aboriginal peoples, or of non-Western people in sustainable tourism research and practice? (see [98,99]). Finally, who is benefitted and who is silenced in the emerging discourse on climate change in sustainable tourism, and how will this affect people in their destination-homelands? [100].

To date, much of the sustainable tourism literature has been written by Western academics, privileging the voice of the (usually) White researcher, and devoid of methodologies and mechanisms that allow for diverse perspectives and voices to come through [101]. Again, while positive changes are occurring on this front, we need to hear much more from the often silenced 'Others', through them doing the researching and writing (e.g., [94]). Moving away from Western ethnocentric perspectives that are often unaware of the situated, diverse body in tourism will also require "alternative" research approaches and theorizings of an ethic of care. There should be greater attention towards the 'Other' and their intangible cultural relationships to 'nature' and to the physical world in which they are embodied and embedded (see, for example, [102]).

\subsection{A Missing Ethic of Justice and Care for Sustainability?}

"Stronger voices from the South are demanding more-representative frameworks of international governance that embody the principles of democracy and equity”. ([103], p. 1)

Even though all countries and regions are demonstrating improvements in human development as gauged by the United Nations Human Development Index (UNHDI), income inequality within and between countries is on the rise. The UN 2013 Human Development report outlined environmental disaster scenarios that could lead to three billion more people living in extreme poverty by 2050 . The report states that "future progress will require policymakers to play close attention to such issues as equity, voice and accountability, environmental risks and changing demography ([103], p. 1). A clear focus on justice and ethics will be increasingly important for resource use and conservation, fair and equitable distribution of scarce resources in the face of urgent planetary sustainability and climate change concerns in 21 st century. The 2012 Rio+20 outcomes as well as the Millennium Development Goals (MDGs) and post-MDG initiatives make poverty alleviation a global priority that is inextricably linked with biodiversity loss, environmental degradation and habitat fragmentation.

While environmental sustainability is indeed crucial, so is the well-being of the people and the places of destinations that are the focus of the tourism industry and mobile travelers. A crucial gap in sustainable tourism research and practice has been theoretical and practical attention to justice and fairness towards those who stand to be most impacted by environmental, social and cultural changes in the complex tourism system. Justice, we argue, has to be furthermore accompanied by care (re-instating those important principles of responsible tourism), particularly to those in developing (and especially poor) regions in the 'South' who bear the consequences of the 'progress' made in the 
developed world since Industrial Revolution' (see [100]). A framework of justice and care may be especially helpful in sustainable tourism to address not only the visible dimensions (e.g., a physical heritage structure) but also the intangible cultural and political dimensions (e.g., the stories and oral histories related to the place, but also aspects such as structural discrimination or racism, for example, in a postcolonial setting where cultural survival of a historically oppressed minority group is at issue). Hence, Scholsberg ([104], pp. 536-537) calls for pluralistic conceptions of justice as it has "multiple, integrated meanings", so for instance, "[d]emands for the recognition of cultural identity and for full participatory democratic rights are integral demands for justice as well, and they cannot be separated from distributional issues."

Jamal and Camargo [92] drew on and adapted earlier work on environmental justice to propose four criteria that could help address and assess tourism development at the destination level, particularly with respect to minority, low-income and disadvantaged groups. These ecocultural justice principles they propose focus on procedural, participative, distributive justice, as well as issues related to discrimination and racism. These authors base the justice intuitions and guidelines described under each criterion on Rawlsian principles (following Rawls, [105,106]). Rawls' difference principle is especially important to ensure consideration towards those who stand to be most impacted, least able to benefit or least able to speak up for themselves, i.e., the poor. It requires that those most disadvantaged become better off through development activities. Hence:

(i) Ecocultural justice with respect to matters of procedural justice enables the active involvement of a destination's resident stakeholders (including indigenous, low-income, diverse and minority groups) in the development and marketing of their ecocultural goods for tourism purposes. It includes attention to participative justice and restorative justice (see [98]).

(ii) Ecocultural equity pertains to issues of distributive justice and equitable, fair distribution of development, marketing and promotion initiatives among different groups, with particular attention to the needs of disadvantaged populations, low income, diverse, and minority groups.

(iii) Ecocultural discrimination refers to the exclusion of individuals, groups and disadvantaged populations from participating in tourism development, marketing planning, and decision-making related to the use and distribution of ecological and cultural goods and services. It includes exclusion due to ethnicity, gender, sexual orientation, and disability, among others.

(iv) Ecocultural racism refers to discrimination and unfair treatment due to race or ethnicity. It is manifested in acts such as disrespect, marginalization, and exclusion of the destination's ethnic group and their ecocultural goods (particularly disadvantaged, diverse and minority groups and individuals) from benefiting from tourism development and marketing. It also includes the accruing of disbenefits such as negative, problematic and stereotypical representation of these groups in tourism-related advertising and promotion.

The above four criteria and their guiding statements fit well with the UNWTO and the 2012 Earth Summit (Rio+20) goals for sustainability [41] as they give priority to the local, to disadvantaged populations and to the poor. Following the difference principle, distributive justice and government policies would be aimed at making the poor as well-off as possible. The principles developed by the Government of South Africa [24] appear to be a constructive example of these Rawlsian principles. 
Their principles encourage government and tourism business to take responsibility to identify projects that benefit the poor and historically disadvantaged, and develop knowledge among these groups so they can access tourism markets and strive towards success in pro-poor tourism. A number of criticisms of the pro-poor tourism approach may perhaps be assuaged by developing a comprehensive framework of justice and care.

Moreover, issues of postcolonial heritage, cultural survival, the role of traditional knowledge, 'co-management', self-empowerment, control over traditional lands and eco-cultural goods, etc., are not simply issues of distributive or procedural justice. They may also related to entrenched discrimination or racism (e.g., towards ethnic or tribal minorities in postcolonial or postapartheid settings (e,g, [94]). Neocolonialism, ecoimperialism, and the issues and concerns raised in the previous section, including cultural fragmentation as human-environmental relationships are rationalized and commodified through ecological modernization and neoliberalism, need an ethic of care, care about the "Other" in tourism destinations. An ethic of care such as discussed in eco-feminism and philosophy would bring emotion, feeling, and good virtues into the justice framework [107,108]. This would enable considerations such as: respect for diversity, recognition of difference, consideration for intangible human-environmental plus social-cultural differences in gender, sex, ethnicity; support of social differentiation and diversity; sympathy, mercy, forgiveness, tolerance, and inclusiveness.

Much work lies ahead to develop a comprehensive framework of justice and care to guide and evaluate sustainable tourism, responsible tourism approaches, and the implementation and management of ecotourism and other tourism forms. Such a framework may help to assess and better ground the multitude of sustainability oriented prescriptions and principles evident in the previous section. They are also required to help address issues of fairness and justice in the destination, particularly with respect to local inhabitants, the rationalization and commodification of their ecological and cultural resources, and their relationships with their natural and cultural heritage. Choi and Sirakaya [109] offer a diverse range of community-based sustainability indicators which, while conflating "issues/indicators", make a good attempt to address some political and cultural dimensions. Intangibles like human-environmental relationships, however, remain unaddressed.

\section{Towards New Directions Forward?}

Industry-driven managerialism that privileges quantification and positivistic approaches has intersected well with the ideological underpinnings of sustainable tourism as it emerged in the late 1980s and early 1990s. This discourse was further influenced by global institutional stakeholders like the UNWTO that adopted the Eurocentric, modernity-based values and goals of 'sustainable development' [1] in its definition and approach to 'sustainable tourism development' [31]. Not surprisingly, the situated 'body' and localized, particular considerations of justice and ethical issues, such as might be related to marginalization and disadvantage in geopolitical postcolonial and neocolonial landscapes, are hardly visible in the macro-level discourses of sustainable tourism and sustainable development. The field is awash with numerous sets of principles, certification schemes and guidelines on ecotourism and sustainable tourism but clear ethical justifications to undergird them are still lagging. 
Responding to perceived negative impacts of tourism and mass tourism, alternative and responsible tourism initiatives and perspectives emerged in the late 1970s and 1980s that focused on local benefits and the well-being of residents and tourists, nature and culture. The pro-poor agenda was a natural fit here. Like the macro-level discourse of 'sustainable development', this micro-level focus has tended to ignore the globalized landscape of power relations that was developing in the 1980s, with dominant scientific narratives dovetailing with increasing neoliberal intrusions in the private and public sphere. Unfortunately, as with the concept of sustainable tourism, clear justice and ethical principles as well as theory building are also lacking in responsible tourism and related emergent approaches such as pro-poor tourism. The resident and the tourist drift in and out of various definitions of ecotourism. And too little attention is paid to the to the social-cultural nexus as Aitchison [101] put it, and cultural intangibles such as human-environmental relationships, and care towards those inhabitants of the destination whose every life is being rationalized and commodified for sale.

As we have argued in this paper, what is required is an integrated local-global, micro-macro, approach to a responsible, sustainable tourism paradigm that is based on something 'other' than the modernity-infused values that permeate current approaches to ecotourism and sustainable tourism. It could help guide the micro-level discourse of responsible tourism, as we do not have clear evaluative guidelines that address justice and ethics in this domain. Given the continued visibility, debates and re-framing efforts around 'sustainable development', it would also make sense to continue (albeit, thoughtfully) with the term 'sustainable tourism but incorporate principles for individual and social well-being, such as are contained in the MDGs, and the post-MDG initiatives; plus a framework of justice and care to help guide and evaluate development and decision making.

Such an integrated, macro-micro ethical framework might better bring into view "fair" practices in resource conservation, such as full-cost accounting plus addressing the transactional politics that West [81] discusses. Called into question by a framework of justice and care, the value of wildlife conservation in popular programs like CAMPFIRE then would hopefully include understanding and care for human-environmental relationships, such as the difference in the everyday lives of the local inhabitants and their situated, everyday and traditional knowledge as they shift into a global geopolitical landscape of climate change, species conservation and international tourism. Waking up to see an elephant in terms of ecotourism dollars is a "change" (not from a romantic relationship either!) that must be addressed through a politics of care. While it is an ethical concern about human well-being, it is also surely a concern about how well 'conservation' will work in the long-term when little heed is paid to such intangibles as ecocultural relationships and other than anthropocentric, modernist, Eurocentric values and ways of doing and being in tourism.

An integrated macro-micro, local-global complex systems perspective, building on Farrell and Twining-Ward [110], along with post colonial sensibilities [111] and a comprehensive framework of justice and care, may thus be useful to adopt in the re-framing of sustainable tourism. We have offered here a preliminary discussion that may help to advance this critical agenda, particularly with respect to fairness and justice for those who stand to be most impacted by tourism development and change. At the same time, and to address these issues, there is a need for reflexivity and critical pedagogies in tourism studies to help re-situate and do academic justice to the "Other" (diverse) body in sustainable tourism research. Incorporating a framework of justice and care in sustainable tourism may perhaps 
also help academics and researchers to be more aware and thoughtful about the complex geopolitical and social-cultural context of tourism development, planning and management.

\section{Conflicts of Interest}

The authors declare no conflict of interest.

\section{References}

1. World Commission on Environment and Development (WCED). Our Common Future; Oxford University Press: New York, NY, USA, 1987.

2. Mowforth, M.; Munt, I. Tourism and Sustainability: New Tourism in the Third World; Routledge: London, UK, 1998.

3. Sharpley, R. Tourism and sustainable development: Exploring the theoretical divide. J. Sustain. Tour. 2000, 8, 1-19.

4. Ateljevic, I.; Harris, C.; Wilson, E.; Collins, F.L. Getting 'entangled': Reflexivity and the 'critical turn' in tourism studies. Tour. Recreat. Res. 2005, 30, 9-21.

5. Ateljevic, I.; Pritchard, A.; Morgan, N. The Critical Turn in Tourism Studies: Innovative Research Methodologies; Elsevier: Amsterdam, The Netherlands, 2007.

6. Holden, P. Alternative Tourism with a Focus on Asia. In Proceedings of the Report of the Workshop on Alternative Tourism with a Focus on Asia, Chiang Mai, Thailand, 26 April-8 May 1984; Ecumenical Coalition on Third World Tourism: Bangkok, Thailand, 1984.

7. Krippendorf, J. The Holiday Makers: Understanding the Impacts of Leisure and Travel; Butterworth-Heinemann: London, UK, 1987.

8. Haywood, K.M. Responsible and responsive tourism planning in the community. Tour. Manag. 1988, 9, 105-118.

9. Smith, V.L. Alternative/responsible tourism seminar. Ann Tour. Res. 1990, 17, 479-480.

10. Harrison, L.C.; Husbands, W. Practicing Responsible Tourism: International Case Studies in Tourism Planning, Policy and Development; John Wiley \& Sons, Inc: Toronto, Canada, 1996.

11. Pennington-Gray, L.; Reisinger, Y.; Kim, J.E.; Thapa, B. Do US tour operators's brochures educate the tourist on culturally responsible behaviours? A case study for Kenya. J. Vacat. Mark. 2003, 11, 265-266.

12. Spenceley, A.; Relly, P.; Keyser, H.; Warmeant, P.; McKenzie, M.; Mataboge, A.; Norton, P.; Mahlangu, S.; Seif, J. Responsible Tourism Manual for South Africa; Department for Environmental Affairs and Tourism: Pretoria, South Africa, 2002.

13. Fulton, R. Tourism of duty. Geographical 2008, 80, 62-63.

14. Wheeller, B. Tourism's troubled times: Responsible tourism is not the answer. Tour. Manag. 1991, 12, 91-96.

15. The Capetown Declaration. Available online: http://www.responsibletourismpartnership.org/ CapeTown.html (accessed on 2 May 2013). 
16. Cooper, C.P.; Ozdil, I. From mass to 'responsible' tourism: The Turkish experience. Tour. Manag. 1992, 13, 377-386.

17. Fennell, D.A. Responsible tourism: A Kierkegaardian interpretation. Tour. Recreat. Res. 2008, $33,3-12$.

18. Hall, D.; Brown, F. Tourism and Welfare: Ethics, Responsibility and Sustained Well-being; CABI: Wallingford, UK, 2006.

19. 25 practical ways to make a difference. Geographical 2003, 75, 105.

20. The Responsible Tourist and Traveller. Available online: http://ethics.unwto.org/sites/all/files/ docpdf/responsibletouristbrochureen.pdf (accessed on 4 May 2013).

21. The Responsible Travel Handbook. Available online: http://www.unique-southamerica-travelexperience.com/support-files/responsibletravelhandbook.pdf (accessed on 4 May 2013).

22. Responsible Tourism Guidelines. Available online: http://www.aito.co.uk/corporate RTGuidelines.asp (accessed on 2 May 2013).

23. White Paper on the Development and Promotion of Tourism in South Africa; Department of Environmental Affairs and Tourism, Government of South Africa, 1996. Available online: http://www.info.gov.za/whitepapers/1996/tourism.htm (accessed on 4 May 2013).

24. National Responsible Tourism Development Guidelines for South Africa; Department for Environmental Affairs and Tourism, Republic of South Africa, 2002. Available online: http://www.tourism.gov.za/CurrentProjects/ResponsibleTourism/Responsible\%20Tourism/Respo nsible\%20Tourism\%20Guidelines.pdf (accessed on 4 May 2013).

25. Kerala Declaration. Available online: http://www.responsibletourism2008.org/keraladeclaration.php (accessed on 4 May 2013).

26. Stanford, D. Exceptional visitors: Dimensions of tourist responsibility in the context of New Zealand. J. Sustain. Tour. 2008, 6, 258-275.

27. Blackstock, K.L.; White, V.; McCrum, G.; Scott, A.; Hunter, C. Measuring responsibility: An appraisal of a Scottish national park's sustainable tourism indicators. J. Sustain. Tour. 2008, 16, 276-297

28. Goodwin, H. Responsible tourism and the market. http:/www.responsibletravel.com/ ImagesClient/certification.pdf (accessed on 4 May 2013).

29. Goodwin, H. Taking Responsibility for Tourism; Goodfellow Publishers Limited: Woodeaton, UK, 2011.

30. Garrod, B.; Fyall, A. Beyond the rhetoric of sustainable tourism? Tour. Manag. 1998, 19, 199-212.

31. Cronin, L. A strategy for tourism and sustainable development. World Leis. Recreat. 1990, 32, 12-18.

32. English Tourist Board. The Future of England's Smaller Seaside Resorts: Summary Report; ETB: London, UK, 1991

33. United Nations World Tourism Organization (UNWTO). Agenda 21 for Travel and Tourism: Towards Environmentally Sustainable Tourism; WTO, WTTC and the Earth Council: London, UK, 1994.

34. Inskeep, E. Tourism Planning: An Integrated and Sustainable Development Approach; Van Nostrand Reinhold: New York, NY, USA, 1991. 
35. Cater, E.; Goodall, B. Must Tourism Destroy Its Resource Base? In Environmental Issues in the 1990s; Mannion, A.M., Bowlby, S.R., Eds.; Wiley: Chichester, UK, 1992; pp. 309-324.

36. Hardy, A.; Beeton, R.J.S.; Pearson, L. Sustainable tourism: An overview of the concept and its position to conceptualizations of tourism. J. Sustain. Tour. 2002, 10, 475-496.

37. United Nations World Tourism Organization (UNWTO). Making Tourism More Sustainable—A Guide for Policy Makers; UNEP and UNWTO: Madrid, Spain, 2005.

38. UNEP-ICLEI. Tourism and Local Agenda 21: The Role of Local Authorities in Sustainable Tourism; United Nations Environment Programme (UNEP) and International Council for Local Environmental Initiatives (ICLEI): Paris, France, 2003.

39. Bramwell, B.; Lane, B. Sustainable tourism: An evolving global approach. J. Sustain. Tour. 1993, 1, 1-5.

40. Humke, M. Sustainable Tourism Enterprise Development: A Business Planning Approach. Sustainable Tourism: International Cooperation for Development. Available online: http://www. usaid.gov/sites/default/files/documents/1865/EnterpriseDev_5\%5B2\%5D.pdf (accessed on 4 May 2013).

41. United Nations. The Future We Want. Rio+20 United Nations Conference on Sustainable Development. Rio de Janeiro, Brazil 2012. Available online: http://www.stakeholderforum.org/ fileadmin/files/FWWEnglish.pdf (accessed on 4 May 2013).

42. Butler, R.W. Sustainable tourism: A state-of-the-art review. Tour. Geogr. 1999, 1, 7-25.

43. Hunter, C. On the need to re-conceptualize sustainable tourism development. J. Sustain. Tour. 1995, 3, 155-165

44. Font, X.; Harris, C. Rethinking standards from green to sustainable. Ann. Tour. Res. 2004, 31, 986-1007.

45. Wood, R.E. Tourism and International Policy: Neoliberalism and Beyond. In The SAGE Handbook of Tourist Studies; Jamal, T., Robinson, M., Eds.; Sage Publications: London, UK, 2009; pp. 595-612.

46. Peterson, T.R. Sharing the Earth: The Rhetoric of Sustainable Development; University of South Carolina Press: Columbia, SC, USA, 1997.

47. Duffy, R. A Trip Too Far: Ecotourism, Politics and Exploitation; Earthscan: London, UK, 2002.

48. Luke,T.W. Ecocritique: Contesting the Politics of Nature, Economy and Culture; University of Minnesota Press: Minneapolis, MN, USA, 1997.

49. Rutherford, P. Ecological Modernization and Environmental Risk. In Discourses of the Environment; Darier, E., Ed.; Blackwell: Oxford, UK, 1999; pp. 95-118.

50. Holden, A. In need of new environmental ethics for tourism? Ann. Tour. Res. 2003, 30, 94-108.

51. Hunter, C. Sustainable tourism as an adaptive paradigm. Ann. Tour. Res. 1997, 24, 850-867.

52. Harvey, D. A Brief History of Neoliberalism; Oxford University Press: Oxford, UK, 2005.

53. Sen, A. Development as Freedom; Oxford University Press: Oxford, UK, 1999.

54. Nussbaum, M. Creating Capabilities: The Human Development Approach; The Belknap Press of Harvard University Press: Cambridge, MA, USA, 2011.

55. Nussbaum, M.; Sen, A. The Quality of Life; Oxford University Press: Oxford, UK, 1993.

56. Mader, R. Ecotourism champion: A conversation with Hector Ceballos-Lascuráin. Available online: http://www.planeta.com/ecotravel/weaving/hectorceballos.html (accessed on 4 May 2013). 
57. Ceballos- Lascuráin, H. The future of ecotourism. Mexico J. 1987, 1, 13-14.

58. Boo, E. Planning for ecotourism. Parks 1991, 2, 4-8.

59. Fennell, D. Ecotourism: An Introduction; Routledge: New York, NY, USA, 1999.

60. Weaver, D.B. Ecotourism in the Less Developed World; CAB International: Wallingford, CT, USA, 1998.

61. Langholz, J. Exploring the effects of alternative income opportunities on rainforest use: Insights from Guatemala's Maya Biosphere Reserve. Soc. Nat. Resour. 1999, 12, 139-149.

62. Weaver, D.B. Magnitude of ecotourism in Costa Rica and Kenya. Ann. Tour. Res. 1999, 26, 792-816.

63. Valentine, P.S. Ecotourism and nature conservation: A definition with some recent developments in Micronesia. Tour. Manag. 1993, 14, 107-115.

64. Ceballos-Lascuráin, H. Tourism, Ecotourism, and Protected Areas; The IUCN Ecotourism Consultancy Programme: México City, Mexico, 1993.

65. The International Ecotourism Society (TIES). What is Ecotourism? Available online: $\mathrm{http} / /$ www.ecotourism.org/what-is-ecotourism (accessed on 5 May 2013).

66. Cater, E.; Lowman, G. Ecotourism: A Sustainable Option? Wiley: New York, NY, USA, 1994.

67. Honey, M. Ecotourism and Sustainable Development. Who Owns Paradise? Island Press: Washington, DC, USA, 1999.

68. Jamal, T.; Borges, M.; Stronza, A. The institutionalisation of ecotourism: Certification, cultural equity and praxis. J. Ecotour. 2006, 5, 145-175.

69. Fennell, D.A.; Malloy, D.C. Ethics and ecotourism: A comprehensive ethical model. J. Appl. Recreat. Res. 1999, 20, 163-183.

70. Hall, M. Ecotourism in the South Pacific. Environmental matters, cultural concerns. Geogr. Rundsch. 1994, 46, 641-646.

71. Dryzek, J.S. Rational Ecology: Environment and Political Economy; Basil Blackwell: Oxford, UK, 1987.

72. Harvey, D. What's Green and Makes the Environment Go Round? In The Cultures of Globalization; Jameson, F., Miyoshi, M., Eds.; Duke University Press: Durham, NC, USA, 1998; pp. 327-355.

73. West, P.; Carrier, J.G. Ecotourism and authenticity. Curr. Anthropol. 2004, 45, 483-498.

74. Weber, M. Science as a Vocation. In Max Weber: Essays in Sociology; Gerth, H.H., Mills, W.C., Eds; Oxford University Press: New York, NY, USA, 1946; pp. 129-156.

75. Berman, M. The Reenchantment of the World; Cornell University Press: Ithaca, NY, USA, 1981.

76. Luke, T.W. Ecocritique: Contesting the Politics of Nature, Economy and Culture; University of Minnesota Press: Minneapolis, MN, USA, 1997.

77. Agrawal, A. Environmentality: Community, intimate government, and the making of environmental subjects in Kumaon, India. Curr. Anthropol. 2005, 46, 161-190.

78. Habermas, J. The Structural Transformation of the Public Sphere, trans. Thomas Burger; MIT Press: Cambridge, MA, USA, 1989.

79. Jamal, T.; Everett, J.; Dann, G.M. Ecological rationalization and performative resistance in natural area destinations. Tourist Stud. 2003, 3, 143-169. 
80. Wearing, S.; McDonald, M.; Ponting, J. Building a decommodified research paradigm in tourism: The contribution of NGOs. J. Sustain. Tour. 2005, 13, 424-439.

81. West, P. Translation, value, and space: Theorizing an ethnographic and engaged environmental anthropology. Am. Anthropol. 2005, 107, 632-642.

82. Jamal, T.; Stronza, A. "Dwelling" with ecotourism in the Peruvian Amazon: Cultural relationships in local-global spaces. Tourist Stud. 2008, 8, 313-336.

83. Jamal, T.B.; Everett, J. Resisting rationalisation in the natural and academic life-world: Critical tourism research or hermeneutic charity? Curr. Issue Tour. 2004, 7, 1-19.

84. Tribe, J. New tourism research. Tour. Recreat. Res. 2005, 30, 5-8.

85. Wilson, E.; Harris, C.; Small, J. Furthering critical approaches in tourism and hospitality studies: Perspectives from Australia and New Zealand. J. Hosp. Tour. Manag. 2008, 15, 15-18.

86. Chok, S.; Macbeth, J.; Warren, C. Tourism as a tool for poverty alleviation: A critical analysis of pro-Poor tourism and implications for sustainability. Curr. Issue Tour. 2007, 10, 144-165.

87. Wilson, E.; Ateljevic, I. Challenging the 'Tourist-other' Dualism: Gender, Backpackers and the Embodiment of Tourism Research. In Backpacker Tourism: Concepts and Profiles; Hannam, K., Ateljevic, I., Eds.; Channel View Publications: Clevedon, UK, 2008; pp. 147-172.

88. Higgins-Desbiolles, F. Justifying Tourism: Justice through Tourism. In Tourism and Inequality: Problems and Prospects; Cole, S., Morgan, N., Eds.; Cabi: Wallingford, UK, 2010; pp. 194-211.

89. Fennell, D.A. Tourism Ethics; Channel View Publications: Clevedon, UK, 2006.

90. Macbeth, J. Towards an ethics platform for tourism. Ann Tour. Res. 2005, 32, 962-984.

91. Higgins-Desbiolles, F. Justice tourism and alternative globalization. J. Sustain. Tour. 2008, 16, 345-364.

92. Jamal, T.; Camargo, B.A. Sustainable tourism, justice and an ethic of care: Toward the just destination. J. Sustain. Tour. (ahead-of-print) 2013, doi:10.1080/09669582.2013.786084.

93. Bunten, A.C. More like ourselves: Indigenous capitalism through tourism. Am. Indian Quart. 2010, 34, 285-311.

94. Akama, J.S.; Maingi, S.; Camargo, B.A. Wildlife conservation, safari tourism and the role of tourism certification in Kenya: A postcolonial critique. Tour. Recreat. Res. 2011, 36, 281-291.

95. Peters, A.; Higgins-Desbiolles, F. Demarginalising tourism research: Indigenous Australians as tourists. J. Hosp. Tour. Manag. 2012, 19, 9.

96. Veijola, S.; Jokinen, E. The body in tourism. Theor. Cult. Soc. 1994, 11, 125-151.

97. Hollinshead, K. Tourism, hybridity, and ambiguity: The relevance of Bhabha's 'Third Space' cultures. J. Leis. Res. 1998, 30, 121-156.

98. Whyte, K.P. An environmental justice framework for indigenous tourism. Environ. Philos. 2010, 7, 75-92.

99. Nielsen, N.; Wilson, E. From invisible to indigenous-driven: A critical typology of research in indigenous tourism. J. Hosp. Tour. Manag. 2012, 19, 1-9.

100. Becken, S. A review of tourism and climate change as an evolving knowledge domain. Tour. Manage. Perspect. 2013, 6, 53-62.

101. Aitchison, C. Poststructural feminist theories of representing Others: A response to the 'crisis' in leisure studies' discourse. Leis. Stud. 2000, 19, 127-144.

102. Mkono, M. African as tourist. Tour. Anal. 2011, 16, 709-713. 
103. United Nations Development Programme (UNDP). Human Development Report 2013: The Rise of the South: Human Progress in a Diverse World. Available online: http:/www.un.ba/upload/ HDR2013\%20Report\%20English.pdf (accessed on 5 May 2013).

104. Schlosberg, D. Reconceiving environmental justice: Global movements and political theories. Environ. Politic. 2004, 13, 517-540.

105. Rawls, J. A Theory of Justice; The Belknap Press of Harvard University: Cambridge, MA, USA, 1971.

106. Rawls, J. Justice as Fairness: A Restatement; Harvard University Press: Cambridge, MA, USA, 2001.

107. Warren, K.J.; Cheney, J. Ecological feminism and ecosystem ecology. Hypatia 1991, 6, 179-197.

108. Torgé, M. Ecotourism in Donsol-ecofeminist perspectives. Master's thesis, Linköpings Universitet, Linköping, Sweden, 2007.

109. Choi, H.C.; Sirakaya, E. Measuring residents attitudes towards sustainable tourism: Development of sustainable tourism attitude scale. J. Travel Res. 2006, 43, 380-394.

110. Farrell, B.H.; Twining-Ward, L. Reconceptualizing tourism. Ann. Tour. Res. 2004, 31, 274-295.

111. Burns, P. Some Reflections on Tourism and Post-colonialism. In Tourism Development Revisited: Concepts, Issues and Paradigms; Babu, S., Mishra, S., Parida, B.B., Eds.; Sage Publications: London, UK, 2008; pp. 64-75.

(C) 2013 by the authors; licensee MDPI, Basel, Switzerland. This article is an open access article distributed under the terms and conditions of the Creative Commons Attribution license (http://creativecommons.org/licenses/by/3.0/). 